\title{
IDENTIFIKASI PELAKSANAAN KERJASAMA DAERAH
}

\section{IDENTIFICATION THE IMPLEMENTATION OF REGIONAL COOPERATION}

\author{
Imam Radianto Anwar Setia Putra \\ Pusat Penelitian Dan Pengembangan Pemerintahan Umum Dan Kependudukan \\ Badan Penelitian Dan Pengembangan Kementerian Dalam Negeri \\ Jln. Kramat Raya No. 132 Jakarta Pusat Tlp. +62 213101953 Hp. +62813 61959598 \\ e-mail: imamradianto@gmail.com \\ Dikirim: 10 Maret 2013; direvisi: 29 April 2013; disetujui: 19 Juni 2013
}

\begin{abstract}
Abstrak
Kerja sama daerah merupakan perangkat dalam mendukung peningkatan kesejahteraan daerah dengan memanfaatkan potensi dan sumberdaya yang dimiliki daerah. indetifikasi ini meihat kemampuan dan pelaksanaan kerja sama daerah, dengan melihat sumberdaya manusia yang dimiliki pemerintah daerah sehingga tujuan dari kerja sama daerah tersebut terpenuhi. Keterbatasan kemampuan daerah dalam mengelola dan memanfaatkan potensi dan sumber daya daerah memerlukan perhatian khusus pada pengelolaan kerja sama daerah untuk menigkata nilai kebermanfaatan dari objek kerja sama daerah. untuk itu dibutuhkan kelembagaan yangkuat dan mekanisme pengawasan dengan aspek yang krusial sesuai dengan semangat pelaksanaan kerja sama daerah.
\end{abstract}

Kata kunci: kerja sama, kelembagaan, kesejahteraan masyarakat

\begin{abstract}
Intergovernmental cooperation is in favor of improving the welfare of the region and the potential to utilize their resources area. Identification and implementation of these look at the ability of regional cooperation, with a view of its human resources so that the objectives of the local government areas of cooperation have been met. The limited ability of the region to manage and utilize the potential and resources of the area requires special attention to the management of regional cooperation for the usefulness of the object value menigkata regional cooperation. for the needed institutional mechanisms with yangkuat and crucial aspect in accordance with the spirit of the implementation of regional cooperation.
\end{abstract}

Keywords: cooperation, institutional, public welfare

\section{PENDAHULUAN}

Kerja sama daerah (KAD) merupakan sarana memantapkan hubungan dan keterikatan antardaerah dalam kerangka NKRI, menyerasikan pembangunan daerah, mensinergikan potensi antardaerah dan/atau dengan pihak ketiga, serta meningkatkan pertukaran pengetahuan, teknologi dan kapasitas fiskal daerah. Kerjasama daerah merupakan usaha/kegiatan yang dilakukan pemerintahan daerah dalam mendukung peningkatan pelayanan dan meningkatkan asessabilitas pembangunan daerah. Pengkajian ini melakukan identifikasi terhadapat pelakasanaan kerjasama daerah yang dilakukan oleh pemerintahan daerah. Kerjasama daerah mendorong berbagai pihak termasuk pemerintah daerah itu sendiri yang berdasarkan keinginan untuk memenuhi tuntutan kebutuhan pelayanan dan peningkatan kualitas. Keyakinan terhadap kerjasama daerah dapat meningkatkan ekonomi daerah, dengan didukung peraturan daerah dan juga sumberdaya aparatur pelaksanaan kerjasama daerah yang memiliki kompetensi sehingga pemerintah daerah memiliki kemampuan dan tidak menjadi bulan-bulan pengusaha di daerah sehingga pemerintah daerah memiliki kemampuan yang mumpuni dalam pelaksanaanya.
Sesuai dengan UU No 32 tahun 2004 tentang pemerintahan daerah pasal 195 terkatub tetang akan kebutuhan kerja sama dalam memningkatkan kesejahteraan masyarakat melalui efektifitas dan efisienasi pelayanan publik dimana bunyi pasal 195 ayat 1 adalah "Dalam rangka meningkatkan kesejahteraan rakyat, daerah dapat mengadakan kerjasama dengan daerah lain yang didasarkan pada pertimbangan efisiensi dan efektivitas pelayanan publik, sinergi dan saling menguntungkan. Selanjutnya ditetapkan peraturan pemerintah nomor 50 tahun 2007 tentang tata cara kerja sama daerah sebagai arahan dan petunjuk dalam pelaksanaan kerja sama daerah sehingga memberikan dampak dalam peningkatan pembangunan di daerah yang pada akhirnya berkolerasi terhadap pemenuhan kesejahteraan masyarakat melalui pemenuhan pelayanan kepada masyarakat dan penyediaan infrastruktur."

Selain itu, manfaat dari penyelenggaraan kerja sama yang dilakukan oleh pemerintahan daerah terjadinya sinergitas dalam pembangunan di suatu kawasan/wilayah sehingga dapat saling memberikan keuntungan bagi daera-daerah yang melakukan kerja sama, serta menekan kebutuhan akan pembiayaan pembangunan di daerah. Kerja sama antara daerah dalam rangka meningkatkan kesejahteraan masyarakat dilakukan secara efektif dan efisien 
dimana efektifitas tersebut memperhatikan petensi daerah dan kemampuan yang dimiliki daerah sehingga dapat membantu dan mendorong pembangunan, tentunya kerja sama daerah merupakan kegiatan yang dilakukan oleh pihak-pihak tertentu dalam mencari keuntungan dan manfaatnya sehingga besar sekali kemungkinan menghadapi kendala, tantangan, dan permasalahan terkait kerjasama daerah tersebut.

Saat ini permasalahan yang timbul yang terjadi di daerah dalam pelaksanaan kerjasama di daerah, dapat dilihat dari sisi-sisi di dalam pelaksanaan otonomi daerah. Seperti inkonsitensi kebijakan antar daerah yang saling bersingungan dalam mengatur hal yang sama ditambah dengan adanya keterbatasan hukum bagi pemerintah provinsi dalam menjembatani kebijakan yang dibuat daerah dalam rangka pelaksanan otonomi daerah (Cahyani, K, 2009). Kapasitas pemerintah daerah dan juga di dukung peraturan perundan-undangan sangat memperngaruhi jalanya kerja sama antar daerah yang dilakukan, tidak hanya itu saja kemampuan penyelenggara pemerintah daerah untuk mensingkronkan dan mensinergikan pembangunan di daerahnya masing-masing dengan mendorong kerjasama sebagai salah satu alat atau metode dalam mendunguknya menjadi perhatikan khususn yang harus diakomodir oleh seluruh pemerintah daerah.

Tak kalah pentingnya, pembentukan kelambagaan dalam kerjasama antar daerah menjadi titik krusial dalam pelaksanaan dengan mekanisme kerja yang tersistematis. Seperti model kerja sama antar daerah pada sekretaris bersama (Sekber) Kartamantul yang memiliki dinilai fleksibel dan menghilangkan batasan struktural tapi terdapat sisi minusnya tidak adanya mekanisme kerja yang dapat digunakan untuk mengukur kinerja sekretaris bersama kartamantul. Penguatan kelembagaan lainnya dengan membentuk perusahaan (pratikno dkk, 2004) ada pula pola kerja sama yang diwujudkan pada pembentukan perusahaan dimana daerah-daerah menjadi sebagai pemegang sahamnya dan lain-lain. Usaha patungan daerah dan pembentukan kelambagaan kembali harus disesuaikan dengan paradigma dan kebutuhan pelaksanaan kerja sama daerah tersebut sehingga timbulah berbagai macam dan pola/bentuk organisasi yang mendukung penyelenggaraan kerja sama daerah, selain itu juga di lapangan keterbatasan dan kemampuan personil yang mendukung penyelenggaraan kerja sama daerah menjadi kebutuhan yang sangat mendesak sehingga diharapkan dapat dipenuhi untuk segera dipenuhi.

"Lebih jauh diterangkan bupati, kerja sama antar daerah diperlukan dengan pertimbangan, semakin majemuknya masalah keperluan dasar masyarakat yang dipicu dengan pertumbuhan penduduk yang tinggi dan penyebaran yang tidak merata. Semakin terbatasnya potensi sumber daya alam dan pengelolaan yang tidak ramah lingkungan, selain itu juga keterbatasan kemampuan dana daerah sehingga memerlukan dana dari sumber lainnya baik dari pemerintah pusat maupun swasta. Menggali potensi unggulan daerah yang belum dikelola secara optimal yang dikarenakan keterbatasan sumber daya manusia (SDM) (Riau Post, 29/05/2013)”

Tantangan kedepan dalam membangun daerah yaitu bagaimana menggali potensi dan memanfaatkan sumber pendaan lain sehingga pembangunan dapat menjadi tanggung jawab bersama seluruh stekeholeder di daerah. Telihat dari cupilak berita di atas menekankan pada keterbutuhan melakukan kerjasama daerah di pelbagai sektor yang sumberdayanya dimiliki oleh daerah dan diharapkan membantu mengurai permasalahan terkait dengan kebutuhan dasar masyarakat. Permasalahan lainnya yang ditangkap yaitu dukungan pendanaan dalam pelaksanaan kerja sama yang diharapkan mendapatkan dukungan pembiayaan yang bersifat bantuan dari berbagai pendanaan yang sah sesuai dengan ketentuan yang berlaku, selain itu tantangan lainnya adalah kemampuan sumberdaya manusia yang dimiliki untuk mendukung penyelenggaraan kerjasama daerah membutuhkan perhatian khusus sehingga unit kerja penyelenggara kerjasama daerah memiliki kemampuan yang baik dan kompetensi yang memadai dalam penyelenggaraan kerjasama daerah.

Beberpa kasus kerjasama daerah yang terjadi yang meliputi dua aspek terkati dengan kebermanfaatanya dari kerjasama daerah yang dilakukan dan pelembagaan kerjasama daerah yang terjadi hingga saat ini, untuk itu di rasa sangat penting melakukan kegiatan kelitbangan dalam mengali informasi kebijakan khususnya pelaksanaan kerja sama daerah melakukan identifikasi profil kerja sama daerah. Identifikasi Profil kerja sama daerah dimaksud mencoba memaparkan tinjauan terhadapt kerja sama daerah dengan melihat dari aspek yaitu: 1) pelaksanaan kerjasama yang dilihat dari mekanisme dan dukungan pemerintah daerah terkait kerjasama yang dilakukan dan 2) pelembagaan kerjasama daerah serta sekaligus menjadi pembatasan pengkajian ini.

Kemampuan kelambagaan di daerah dalam mendukungpelaksanaan kerja sama daerah membutuhkan dukungan dari semua pemangku kepentingan. Pemerintah, dalam penyelenggaraan kerja sama daerah di batasi arena administrasi serta batas-batas fungsional yang ada, maka dari itu ditekankan pada kemampuan pemerintahan daerah dalam melakukan kerja sama sehingga dapat saling menguntukan dan bisa menghasilkan sinergitas dalam pembangunan di daerah. Kerja sama seperti apa saja yang sudah dilakukan oleh pemerintahan daerah. Pertanyaan kajian ini, yaitu: 1) Bagaimana pelembagaan kerja sama daerah yang dilakukan oleh pemerintah daerah?.

Pengkajian (kajian Strategi) ini memiliki tujuan memetakan pelaksanaan kerja sama di daerah serta usaha apa saja yang dilakukan oleh pemerintah daerah sehingga didapat upaya untuk mengatasi kendala/tantangan yang menghambat kerja sama 
daerah tersebut. Sasaran dalam pengkajian ini menghasilkan profil kerja sama daerah, yang dilaksanakan oleh pemerintahan daerah di beberapa wilayah di indonesia. Kajian strateis ini membagi wilayah pengkajian berdasarkan besaran industri yang dimiliki di enam koridor MP3EI. Studi ini dapat menjawab pertanyaan kajian yang dirumuskan serta juga memperhatikan keterbatasan pelaksanaan pengkajian.

Ruang lingkup studi ini menitik beratkan pada pemetaan pelaksanaan kerja sama di daerah yang dilakukan pemerintah daerah dengan pemerintah daerah lainnya atau/dengan pihak swasta dan juga berusaha memetaka profil pelaksanaan kegiatan kerja sama yang dilaksanakan oleh pemerintah daerah sekaligus untuk melihat daya saing yang dimana seperti yang sudah di jelaskan di atas kerja sama antar daerah dapat meningkatkan daya saing daerah.

\section{Kerja Sama Daerah}

Peraturan Pemerintah (PP) No 50 Tahun 2007 tentang Tata Cara Pelaksanaan Kerja Sama Daerah menyatakan, yang dimaksud dengan kerja sama daerah adalah kesepakatan antara gubernur dan gubernur, atau gubernur dan bupati/wali kota, atau antara bupati/wali kota dan bupati/wali kota yang lain, dan atau gubernur, bupati/wali kota dan pihak ketiga, yang dibuat secara tertulis serta menimbulkan hak dan kewajiban. Terdapat minimal dua aktor publik yang menjadi pengerak dalam pelaksanaan kerja sama di daerah dengan berupaya untuk saling mengikat untuk dapat mengelolan dan mendatangkan kebermanfaatan dengan mengunakan sumberdaya dan potensi yang dimiliki oleh aktor-aktor publik di daerah yang memiliki tanggung jawab dalam penyelenggaraan pemenuhan pelayanan pubilik dalam meningkatkan kesejahteraan masyarakat di daerah.

PP 50 tahun 2005, pelaksanaan kerjasama daerah yang menjadi objek kerjasama daerah meliputi seluruh urusan pemerintahan yang menjadi kewenangan daerah otonom dan dapat berupa penyediaan publik. Selanjutnya kerjasama daerah tersebut dituangkan dalam bentuk perjanjian kerjasama daerah (PKS). Selanjunya yang menjadi aktor dalam pelaksanaan perjanjian kerja sama dapat dilakukan oleh Satuan Kerja Perangkat Daerah (SKPD) dengan persetujuan DPRD juga dalam rangka pelaksanaan tugas dan fungsi dari SKPD tersebut. Kerja sama daerah dilakukan dengan prinsip-prinsip yang sudah ditetapkan, dalam penyusunan rancangan perjanjian kerjasama paling sedikit memuat, antara lain: 1) Subjek kerjasama; 2) Objek kerja sama; 3) Ruang lingkup; 4) Hak dan kewajiban para pihak; 5) Jangka waktu kerja sama; 6) Pengakhiran kerja sama; 7) Keadaan memaksa; dan 8) Penyelesaiaan perselisian..

Sesuai dengan Permendagri Nomor 22 tahun 2009 dan 23 tahun 2009 Pelaksanaan kerjasama daerah juga didukung dengan membentuk Badan kerjasama daerah yang ditentapkan oleh keputusan kepala daerah dalam mendukung kerjasama dengan daerah lain dilakukan secara terus-menerus atau diperlukan waktu paling singkat 5 (lima) tahun, badan kerjasama daerah melakukan tugas seperti membantu melakukan pengelolaan, monitoring, dan evaluasi terhadap pelaksanaan kerjasama daerah dan juga memberikan masukan, saran dan menyusun laporan kepada kepala daerah.

Selanjutnya dalam mempersiapkan kerjasama daerah dibentuk Tim Koordinasi Kerja Sama Daerah (TKKSD) kepala daerah dapat membentuknya dengan peraturan kepala daerah. TKKSD dimaksud untuk mempersiapkan dan melakukan pembinaan terhadap setiap pelaksanaan Kerja sama daerah. Tugas TKKSD terdiri dari pejabat struktural di lingkungan pemerintah daerah serta mengakomodasi tim pakar guna mendukung dan memperhatikan pra pembentukan kerjasama daerah hingga pembinaan dan pengawasan pelaksanaan kerja sama daerah dimaksud.

Kerja sama antar pemerintahan daerah (inter Governmental Cooperation), Patterson (2008) di definisikan sebagai "an arrangement between tow or more governments for accomplishing common goals, providing a service or solving a mutual problem". Makna dari susunan kalimat tersebut adalah Pengaturan antara satu pemerintah atau lebih untuk mencapai tujuan bersama, memberikan layanan atau memecahkan masalah bersama". Pengertian diatas menyiratkan kepada tujuan yang ingin didapat dengan melakukan kerja sama sebagai alat dalam memberikan pelayanan dan pemecahan permasalahan lainnya dalam penyelenggaraan pemerintahan.

Kerja sama antar daerah yang meliputi dua atau lebih pemerintahan daerah menurut Feiock (2004) meliputi persetujuan antar dua atau lebih pemerintahan daerah; koalisi antar pemerintah daerah dalam upaya untuk memperoleh bantuan atau hibah dari pemerintah pusat; kerjasama pemerintah dan swasta (Public Private Partnership); dan otoritas metropolitan (metropolitan authority). Merurut Feiock membagi membagi ke dalam dua sifat pelaksanaan kerja sama di daerah dengan maksud mendapatkan bantuan yang disediakan.

Kerja sama senantiasa menempatkan pihakpihak yang berinteraksi itu pada posisi yang seimbang, serasi, dan selaras (Pamudji, 1985). Menjelaskan kesamaan posisi dalam penyelenggaraan kerja sama daerah, memiliki kedudukan dan kepentingan yang sama sehingga dapat keterpaduan dan semangat yagn sama dalam mendukung pelaksanaan kerja sama dalam usaha peningkatan kesejahteraan di daerah.

Beberapa faktor yang mempengaruhinya yaitu dalam Young, Oran, R, (1992): 1) Transparansi; 2) kekokohan dan keluasan; 3) Perubahaan aturan; 4) Kapasitas pemerintahan; 5) Distribusi kekuasaan; 6) tingkat ketergantungan antar anggota (pemerintah daerah); dan 7) Ide intelektual. Ketujuh faktor tesebut membangun kerjasama untuk menjadi lebih efisien, selain itu juga membutukan kelembangaan dan tata laksana dalam pengelolaan kerja sama daerah. Kebutuhan akan kerja sama di daerah menjadi sangat penting meningat keterbatasan serta sumberdaya yang dimiliki yang berbeda di setiap daerah. 


\section{METODE PENELITIAN}

Metode yang digunakan dalam pengkajian mengunakan pedekatan kuantitatif dengan metode eksporatif dengan menitik beratkan pada pemetaan profil kerja sama di daerah dengan memperhatikan 3 (tiga) dimensi yang akan diukur dalam pelaksanaan pengkajian ini. Teknik pengumpulan data dilakukan dengan menggunkan tiga cara, yaitu: 1) Survei; 2) Wawancara dan 3) Studi Literatur. Sifat data yang diambil yaitu data kualitatif dan data kuantitatif. Menurut Bogdan dan Taylor dalam Moleong (2002), metode kualitatif merupakan prosedur penelitian yang akan menghasilkan data kualitatif berupa kata-kata, tertulis atau lisan dari orang-orang dan suatu proses yang diamati. Mengali informasi pelaksanaan kerja sama daerah dari informan terdiridari birokrat, politisi, dan para pemangku kepentingan pelaksanaan kerja sama daerah

Data yang dihasilkan dari pengunakan teknik pencarian data tersebut terdiri dari data primer dan data sekunder untuk itu digunakan teknik analisis data deskritif. Sedangkan Miles (1992) menyatakan bahwa, data kualitatif merupakan sumber dari deskripsi yang luas dan berlandasan kokoh, serta memuat penjelasan tentang proses-proses yang terjadi dalam lingkup sektoral.

\section{Pemahanan terhadap Kerja Sama Daerah}

Permasalahan pemahaman terhadap potensi dan sumberdaya yang dimiliki daerah dalam pelaksanaan kerja sama daerah merupakan titik awa dan vital untuk mendalami pelaksanaanya. Pemerintah daerah harus menyadari nilai kebermanfaatan dari sebuah kerja sama yang dilakukan dari sana pemerintah daerah sudah melakukan investasi melalui pembiayaan kegiatan pengelolaan kerja sama daerah untuk dapat membangun sinergitas dalam meningkatkan kesejateraan masyarakat dengan pihak-pihak lain dalam melakukan kerja sama daerah.

Menggali pemahaman kerja sama daerah tersebut dimulai mencari dan mengali potensi dan sumber daya yang menjadi proritas untuk dijadikan objek kerja sama. Dengan demikian pemerintah daerah harus benar-benar mengetahui mengapa potensi dan sumberdaya itu dipilih menjadi objek kerja sama. Selanjutnya, dengan memanfaatkan informasi potensi dan sumberdaya daerah yang dimiliki dapat dipilih menjadi objek kerja sama daerah. tidak berhenti disitu saja pemahaman kerja sama daerah juga harus dikuasai terkait dengan pemanfaatan dari kerja sama tersebut sehingga kerja sama yang dilakukan memang suatu kebutuhan dari pemerintah daerah untuk mendukung dna meningkatkan kesejahteraan masyarakat melalui pemenuhan pelayanan publik dan penyediaan infrastruktur daerah.

Potensi dan kemampuan daerah yang sangat memiliki varian yang tinggi, tingginya varian tersebut dilandaskan berdasarkan kepada letak yang berbada dan potensi serta sumber daya alam yang berbeda pula. Indonesia yang pulau-pulaunya dipisahkan oleh laut dan perairan memiliki keunggulan sekaligus keterbatasan kemampuan untuk dapat mengelolannya dan memanfaatkannya.

Penyelenggaraan pemerintahan daerah sesuai dengan UU 32 tahun 2004 tentang pemerintahan daerah. Membuka peluang pada pemeritah daerah untuk melakukan kreasi dan inovasi dalam meningkatkan dan mensejahterakan masyarakatnya. Oleh karena itu dibukan peluang dalam melakukan kerja sama daerah dalam mendukung dan mempercepat kesejahteraan masyarakat. Kemampuan daerah dalam melihat dan memanfaatkan sumberdaya dan potensi yang dimiliki menjadi salah satu hal yang sangat vital dalam mendukung penyelenggaraan kerja sama daerah. pemerintah daerah sendiri harus memiliki pengetahuan yang memadai dalam menggali potensi daerah dan menggali sektor-sektor yang dapat memberikan peningkatan kesejahteraan kepada masyarakat sehingga dapat berupaya untuk memanfaatkan potensi dan sumberdaya tersebut.

Keterbatasan kemampuan dan kehadalan pemerintah daerah sangat terasa dalam mengali dan mengelola potensi dan sumberdaya yang dimiliki, maka untuk itu ruang kerja sama daerah dibuka untuk memfasilitasi sekaligus memberikan kesempatan kepada pemerintah daerah dalam pengelolaan potensi dan sumber daya yang dimiliki. Setidaknya pemerintah daerah, mempu memetakan potensi dan sumberdaya yang dapat dimanafaatkan pengelolaanya bersama dan menjadikan sebagai objek kerja sama, sehingga keterbatasan kemampuan daerah dalam pengelolaan sumber tersebut dapat terpenuhi. Pemetaan potensi dan sumberdaya yang dijadikan objek kerja sama tersebut dilakukan dengan menilai seberapa besar kebermanfaatanya bagi peningkatan kesejahtaraan masayrakat dan penyelenggaraan pelayanan publik.

Pemahaman kerja sama daerah menyentuh pada potensi dan sumberdaya yang paling memiliki nilai ekonomi yang tinggi. Potensi unggul yang dianggap menjadi sangat paling bernilai dalam memenuhi kebutuhan kesejahteraan dan pelayanan kepada publik yang di miliki pemerintah daerah dengan didukung dengan sumber daya manusia yang memumpuni serta pengorganisasi yang baik setidanya menjadi nilai untuk menetapkan bahwa potensi yang dimiliki pemerintah daerah tersebut dapat diapresiasi pada kerja sama daerah baik itu yang hasilnya akan masuk pada pendapatan asli daerah ataupun yang menjadi dukungan terhadap penyelenggaraan pelayanan publik dan peningkatan kulitas sumberdaya manusia di daerah.

Selain itu, kerja sama daerah juga memerlukan tenaga yang besar dari pemerintah daerah yang menyelenggarakannya. Tenaga yang dimaksud mulai dari pengetahuan perencanaan kerja sama daerah yang merupakan langkah penting dalam mencari dan menetukan seberapa besar nilai manfaat dibadingkan dengan tenaga yang dikeluarkan oleh pemerintah daerah dan untuk hal tersebut setidakan perencanaan harus disiapkan terlebih dahulu. Regulasi dari sektor lain memerlukan singkronisasi sehingga dapat saling mendukung dalam pelaksanaan kerja sama daerah. 
selain dari regulasi dirasa dibutuhkan bantuan pendanaan dari pemerinta dalam mendukung pelaksana kegiatan kerja sama daerah tersebut. dirasakan dibutuhkan bantuan tersebut untuk dapat memfasilitasi peningkatan kemampuan aparatur yang melaksanakan fungsi teknis dari kerja sama daerah.

Selama ini pemerintah daerah sudah memiliki tujuan dalam pelaksanaan kerja sama daerah, tetapi sayangnya tujuan tersebut tidak tergambar secara nyata dalam menuntun penyelenggaraan kerja sama daerah. hanya membaca peraturan perundangundangan yang berlaku dengan menindaklanjuti dan seharusnya diikuti dari tujuan- atau serangkaian tujuan dari yang ingin dicapai dalam kerja sama daerah teresebut. Setidaknya pemerintah daerah memiliki perencanaan yang matang, sektor atau sumberdaya apasaja yang dimiliki daerah yang dapat dikerjasamakan oleh pihak lain, sehingga pengidentifikasian dan pemetaan pelaksanaan kerja sama disetiap tahun anggaran dapat sudah terumuskan. Dengan demikian butuh manajemen perencanaan kerja sama daerah yang disusun baik untuk dapat dipedomi dalam melaksanakan kerja sama daerah

Kerja sama daerah dimulai dari tahap persiapan, yang dimaksudkan disini pemerintah daerah melakukan pemetaan secara mendalam terkati dengan potensi, sektor, dan sumber daya yang dimiliki oleh daerah yang akan dijadikan objek kerja sama. Pemetaan tersebut dijadikan alat ukur dalam memahami secara mendalam sampai nilai kebermanfaatan yang akan didapat oleh para pihak kerja sama dan pemerintah daerah. pemetaan tersebut didukung oleh data dan informasi yang dimiliki oleh pemerintah daerah itu sendiri, langkah awal ini nantinya menjadi gambaran secara untuh terhadap potensi dan sumberdaya yang bisa dimanfaatkan secara bersama-sama dengan pihak lain dalam melakukan kerja sama daerah. untuk itu pengalian terhadap objek yang dikerjasamakan menjadi sangat penting, dibutuhkan kreatifitas dari pihak pemerintah daerah dalam menggali objek-objek kerja sama daerah.

Pemerintah daerah dalam menetapkan dan menggali potensi dan sumberdaya yang dimiliki daerah terlihat belum dilandasi dasar yang matang dan tepat. Selama ini pemilihan atau pengalian sektor belum dilihat sebagai suatu upaya yang sangat memiliki pengaruh sangat besar dalam mencapai nilai keberhasilan dan nilai manfaat dalam pada setiap pelaksanaan kerja sama daerah. penggalian potensi tersebut menjadi batu pijakan awal dalam menetapakan potensi dan sumberdaya daerah menjadi objek dari kerja sama tesebut.

Penetapan potensi atau sumberdaya daerah yang menjadi objek kerja sama daerah terlihat masih diambil berdasarkan pertimbangan struktural dan disesuaikan dengan urusan pemerintah daerah yang diselenggarakan. Untuk beberapa kerja sama yang bersifat pelayanan kepada masyarakat, pemerintah daerah memiliki Satuan Kerja Perangkat Daerah (SKPD) mememiliki peran melaksanakan kegiatan di sektor masing-masing jadi dengan mudah pemerintah daerah yang berperan sebagai eksekutif di daerah menetapkan SKPD terkait yang memiliki peran yang sama sesuai dengan objek kerja sama. Pada tahap awal dalam inisiasi kerja sama tersebut setidaknya ada yang memberikan dukungan terhadap penguatan dan sekaligus menilai kebermanfaatan penyelenggaraan kerja sama tersebut. unit kerja yang membidangi kerja sama daerah tersebut bagi Sub Bagian kerja sama atau pun bagian kerja sama daerah dapat melakukan inisiasi awal dalam mendukung pelaksanaan kerja sama sehingga keuntungan bagi pemerintah daerah tersebut sudah dapat dinilai dan nampak dari awal sebelum perjanjian kerja sama tersebut di tanda tangani.

Terlihat ada peran lainnya yang harus dimainkan diawal pada tahap inisiasi kerja sama daerah. Unit kerja yang memilik peran persiapan tersebut perlu memperhatikan tahapan inisiasi ini, banyak yang didapat dari tahap persiapan sehingga memberikan manfaat yang berkelanjutan dalam pelaksanaan kerja sama daerah. Vitalnya persiapan pelaksanaan kerja sama daerah menentukan kebermanfaatan dari kerja sama tersebut bagi pemerintah daerah sendiri, kebermanfaatan tersebut bisa jadi untung yang diperloleh dari kerja sama daerah tersebut atau kerugian yang di dapat bagi pemerintah daerah itu sendiri. Dengan demikian menjadi sangat penting bagi pemerintah daerah untuk memperhatikan dengan sunguh-sunguh dari berbagai aspek sehingga kerja sama yang dilaksanakan dapat menghasilkan keuntungan disemua pihak yang melaksanakan kerja sama daerah.

Pelaksanaan kerja sama daerah, membutuhkan perencanaan yang matang dalam melakukan kerja sama daerah, kekuatan pemerintah daerah dalam melakukan kerja sama tersebut terdapat pada klausula/pasal yang banyak memberikan kebermanfaatan bagi pemerintah daerah itu sendiri. Sementara ini pemerintah daerah konsetrasi pada pelakasaan kerja sama daerah. terkadang pemerintah daerah "terkecoh" dalam penyusunan perjanjian kerja sama daerah yang dibuatnya bersama dengan pihakpihak yang melakukan kerja sama daerah, nilai manfaat dari kerja sama tersebut menjadi sangat minim sekali dalam memenuhi kebutuhan dan penigkatan pada pemasukan asli daerah. pemerintah daerah tidak begitu mendalami dan mengetahui secara terperinci tentang tiap kalsual/pasal per pasal dalam perjanjian kerja sama daerah.

Pada manajemen perencanaan tentunya menghasilkan rencana strategis dan rencana oprasional pelaksanaan kerja sama daerah. dimana perencanaan strategi kerja sama daerah yang dimaksudkan disini menentukan arah dan tujuan dari kerja sama daerah yang akan dilakukan dalam rangka mengimplementasikan pelaksanaan kerja sama daerah sebagai salah satu tujuan untuk peningkatan kerja sama daerah. selanjutnya rencana oprasional kerja sama daerah merupakan rencana detail yang akan menjabarkan rencana strategis sehingga dapat direalisaiskan kedalam pelaksanaan kerja sama sehari-hari yang akan dilakukan oleh unit yang 
memiliki peran kerja sama daerah dan SKPD yang menjadi pelaksananya.

Kekuatan internal pemerintah daerah juga menjadi penentu terhadap keberhasilan kerja sama daerah. permasalahan sumber daya manusia memang sangat pelik, mulai dari mutasi/rotasi pegawai sampai kepada kompetensi SDM yang dimiliki oleh pemerintah daerah baik mulai dari tahapan persiapan, pelaksanaan dan tahapan akhir kerja sama daerah. tidak dipungkiri masalah SDM dan kemampuanya menjadi salah satu faktor dalam penyusunan klausal dalam perjanjian kerja sama daerah.

Meminimalisir kesalahan dalam rancangan perjanjian kerja sama daerah setidaknya dalam penyusunannya perlu diperkuat dengan analisi hukum kerja sama daerah, sehingga pemerintah daerah tidak merasa "kecolongan" pada saat pelaksanaan kerja sama daerah tersebut berlangsung. Sehingga pada awalnya analisis terhadap kerja sama yang akan dilakukan sangat dibutuhkan dalam menjaga posisi dan kekuatan pemerintah daerah dalam pelaksanaan kerja sama tersebut.

Dukungan perencanaan juga didapat dari kesiapan SKPD yang akan melaksanakan serta peraturan perundang-undangan yang berlaku. pada perencanaan juga memperhatikan dukungan eksternal dari penyelenggaran kerja sama daerah yang merupakan unit kerja pemerintah daerah. artinya pelaksanaan kerja sama daerah dipengaruhi terhadap peraturan perundnag-undnagna sektoral yang mengatur juga pelaksanaan kegiatan kerja sama pada wilayah kerja sektoral tertentu, sehingga sinergitas menjadi penting dalam menjaga dan melaksanakan kerja sama daerah tersebut."kerja sama daerah pada sektor transimigrasi misalnya ada ketentuan tertentu dalam penyelenggaraan kerja sama tersebut. dukungan dari pihak yang berkerja sama daerah pengirim dan daerah penerima tenaga teransmigrasi memiliki ketentuan yang membutuhkan kesepakatan dan perencanaan yang baik dalam mengelola kerja sama transmigrasi tersebut, mulai dari pengiriman teransmigrasi, penematan transmigrasi samapai dengan pengelolaan transmigrasi di daerah transmigrannya.

Pelaksanaan kerja sama daerah tidak lepas juga dalam penyusunan perjanjian kerja sama daerah, dari perjanjian kerja sama tersebut ditetapkan tugas dan peran masing-masing pihak dalam melakukan kerja sama daerah. perjanjiaan tersebut menentukan posisi para pihak yang melakukan kerja sama daerah. pemerintah daerah mempersiapkan perjanjian kerja sama tersebut secara komferhensif dengan memperhatikan secara detai tiap klusul pasal yang terdapat di perjanjian kerja sama daerah tersebut sehingga pemerintah daerah tidak merasa di rugikan atau terkecoh dengan perjanjian kerja sama tersebut. selama ini masih banyak pemerintah daerah dari pengalaman yang didapat dari hasil pengumpulan data lapangan, pemerintah daerah masih belum maksimal membuat perjanjian kerja sama daerah tersebut. sehingga mendatangkan kemanfaatan yang kurang maksimal dalam perlaksanaan kerja sama daerah.
Kemampuan SDM yang sangat terbatas baik kompetensi dan profesionalisme dalam melaksanakan tugasnya merupakan suatau kebutuhan yang sangat mendesak pada pelaksanaan kerja sama daerah. membangun sebuah komitmen dan kompetensi yang dibutuhkan dalam pelaksanaan kerja sama daerah menjadikan suatu hal yang dibutuhkan pada saat ini. diharapkan kemampuan SDM tersebut juga sampai dapat memaparkan nilai kebermanfaatan dari pelaksanaan kerja sama daerah yang dilaksanakan. Tidak hanya sebatas memiliki SDM yang berkomitmen dan berkompetensi saja, penyelenggaraan kerja sama daerah juga membutukan "penjaga" atau organisasi yang mendukung pelaksanaan kerja sama daerah tersebut. dari lokasi yang dijadikan daerah studi beberapa daerah sudah memiliki unit kerja yang dapat memfasilitasi penyelenggaraan kerja sama daerah, hingga saat ini belum di ketahui ukuran dan bentuk unit kerja yang sesuai untuk dapat mengemban pelaksanaan kerja sama daerah.

Selain itu juga Sumberdaya manusia menjadi kunci dalam penyusunan dan penetapan konsepsi kerjasama daerah yang dilakukan selama ini, koreksi mendalam terkait dengan bentuk naskah kesepahaman dan perjanjian kerjasama saat ini masih belum secara detail dirumuskan sehingga menghasilkan dampak yang negatif bagi sebelah pihak. Nota kesepahaman perjanjian kerjasama harus benar-benar mengakomodir kebutuhan kerjasama dan menigkat pihak-pihak yang melakukan kerjasama. Mengingat selama ini terjadi ke kosongan dalam menjaga komitmen bersama setiap tahap pelaksanaan kerjasama, ada beberapa kesepakatan perjanjian kerjasama yang tidak memiliki sangki bagi pihakpihak yang melakukan wan-prsetasi pada tahapan pelaksanaan kerja sama tersebut.

Penyusunan perjanjian kerja sama daerah tersebut dibutuhkan analisi hukum perjanjian kerja sama daerah. analisi hukum tersebut dapat memperkuat posisi pemerintah daerah dalam pelaksanaan kerja sama daerah. analisi hukum ini setidaknya dipersiapkan terlebih dahulu sebelum penyusunan perjanjian kerja sama dengan demikian perjanjian kerja sama tersebut memperhatikan jenis dan sifat pelaksanaan kerja sama yang dilakukan oleh pemerintah daerah dengan pihak-pihak yang terkait di dalamanya.

Analisi hukum perjanjian kerja sama daerah pada struktu yang ada di unit kerja daerah masih terpisah dan dimasukkan ke dalam bagian atau sub bagian hukum dan perundang-undangan yang diselenggarakan di bawah sekretaris daerah. analisis hukum sdiperlukan dalam penyususnan perjanjian kerja sama untuk itu harus dipahami secara mendalam terkait dengan pelaksanaan kegiatan kerja sama daerah mulai dari awal hingga tahapan akhir kegiatan kerja sama sehingga tidak ada yang merasa saling merugikan atau keberatan yang terjadi dalam penyelenggaraan kegiatan kerja sama daerah tersebut.

Perjanjian kerja sama dengan analisis hukum yang kuat menjadi prioritas awal dalam mengawali persiapan kerja sama daerah. kedua materi tersebut 
menjadi satu kesatuan yang utuh dalam pelaksanaan dan menjadi hal yang penting dan menentukan posisi pemerintah daerah sebagai pelaksana atau pihak kerja sama dan juga sebagai pemilik sebagaian modal pada kerja sama daerah yang diselenggarakan.Perjanjian kerja sama memuat ketentuan yang sudah diatur oleh peratuan perundang-undangan, penekanan pada perjanjian kerja sama daerah dukungan regulasi kerja sama daerah yang juga akan membawa pelaksanaan kerja sama tersebut pembagian keuntungan bersama dair pihak-pihak yang melakukan kerja sama daerah. diharapkan dengan melakukan analisis hukum pada penyusunan kerja sama daerah terjadi penguatan kapasitas pemerintah daerah.

Penigkatan kapasitas tersebut dimulai dari SDM yang dimiliki dan disiapkan guna pelaksanaan kerja sama daerah. sesuai dengan Permendagri No. 19 tahun 2009 tentang pedoman peningkatan kapasitas pelaksanaan kerja sama daerah. pada pasal 2 penigkatan kapasitas pelaksanaan kerja sama terbagai kepada 7 kegiatan yang dilakukan untuk meningkatkan kapasitas dalam penyelenggaraan kerja sama daerah. ketujuh kegiatan tersebut akan banyak sekali permasalahan yang dihadapi baik di tingkat pemerintah dan pemerintah daerah masalah pendanaan atau fasilitator dalam mendukung pelaksanaan peningkatan kegiatan tersebut. pemasalahan tersebut juga dirasakan oleh pemerintah daerah yaitu minimnya peningkatan kapasitas yang didapat oleh pemerintah daerah, selama ini kuantitas pelaksanaan peningkatan kapasitas tersebut dalam menjaga kulitas SDM pemerintah daerah.

\section{Kelembagaan Kerja Sama Daerah}

Selain sistem dan prosedur, pelembagaan kerja sama daerah juga tekait dengan kedudukan unit kerja yang menyelenggarakan kerja sama tersebut, seperti yang telah diuraikan pada paragraf di atas, kedudukan unit penyelenggaran peran kerja sama daerah yang ukuran unit kerjanya diukur dengan beban kerja yang dimiliki juga sebagai koordinator dalam penyelenggaraan seluruh peran kerja sama daerah yang terangkup pada kebijakan dan peraturan perundang-undangan yang menjadi acauan dalam menyelenggarakan kerja sama daerah. Budaya dalam pelaksanaan kerja sama daerah menjadi satu hal yang tidak dapat dipisahkan. Dari Sisdur yang ada terciptalah nilai/norma-norma yang akan menjadi suatu budaya dalam unit kerja. budaya tersebut setidaknya mendukung pelembaganan kerja sama yang dilakukan oleh pemerintah daerah.

Bentuk dan ukuran unit kerja yang mendukung sekalingus juga menyelenggarakan kerja sama daerah dapat diukur melalui beban tugas yang di hadapi pada setiap daerah, beban tersebut ditinjau dari jumlah kerja sama yang dilakukan dan juga pemanfaatan kerja sama tersebut dalam meningkatkan kesejahteraan masyarakat yang digambarkan melalui urusan wajib dan urusan pilihan daerah. selain itu dibutuhkan regulasi daerah yang kuat demi mendukung terselenggaranya kerja sama daerah, sistem dan prosedur (Sisdur) harus dibuat dan ditaati oleh seluruh pemangku kepentinga pemerintah daerah dalam menuntun dan melaksanakan kerja sama daerah.

Penyelenggaraan pemerintah daerah yang terkait dengan koordinasi pelaksanaan kegiatan terdapat sedikit hambatan. Hambatan dimaksud melihat posisi serta tingkatan dari unit kerja yang melaksanakan kegiatan. Koordinasi yang bersifat vertikal diperlukan kebesaran jiwa pada setiap pelaksananya untuk dapat menjalankan kegiatan tersebut dan membuat pelaksanaan kegiatan tersebut menjadi berhasil, selain itu, koordinasi ditingkat horizontal, antara pemerintah provinsi dan pemerintah kabupaten/kota diperlukan skema dan alur kooridinasi yang ditata dan dijadikan sebuah norma sehingga dapat secara kontinyu dan berkesinambungan terlaksana. Untuk dapat menghilangkan gejala tersebut dubutuhkan koordinasi dan komunikasi yang intens dan partisipatif ditiap jajaran pemerintah daerah yang menyelenggarakan kerja sama daerah.

Mendukung pelaksanaanya unit kerja diberikan dikonstruksikan suatu struktur organisasi dengan ukuran yang tepat dan ditambahakan kewenangan yang harus didapat dalam mendukung pelaksanaan kerja sama daerah. sehingga dalam berkoordinasi pun bisa berjalan baik sekalipun unit kerja tersebut memiliki tinggkatan yang rendah dalam struktur birokrasi di pemerintah. Kewenangan diperlukan sehingga mampu melaksanakan kerja sama daerah dengan baik. Pemberian kewenagan tersebut setidaknya meberikan peran yang cukup berarti bagi unit kerja penyelenggaran peran kerja sama daerah untuk dapat lebih intens lagi dalam mendukung pelaksanaan kerja sama daerah sehingga diharapkan dapat mendeteksi lebih dini terhadap permasalahan kerja sama daerah yang akan terjadi dan juga membantu penyelesaian perselisian kerja sama yang merupakan peran yang tidak dapat dipisahkan

Penyelenggaraan kerja sama daerah yang menjadi sebuah alat dalam mendukung peningkatan kesejahteraan masyarakat dalam mengelola potensi dan sumberdaya daerah dengan minimnya sumberdaya pendanaan, kerja sama daerah menjadi perangkat yang sangat efektif untuk itu dubutuhkan kemamuan dan kreatifitas penyelenggaran pemerintah daerah dalam memanfaatkannya. Tidak kalah pentingnya penyelenggaraan kegiatan juga setidaknya diikuti dengan dukungan evaluasi tata laksana kerja sama daerah yang tepat dan baik pula, untuk itu evaluasi dalam penyelenggaraan kerja sama daerah dititik beratkan pada upaya pemerintah daerah dalam melaksanakan yang meliputi tiap tahapan pelaksanaan kerja sama daerah (prosedur pelaksanaan kerja sama daerah) dan juga melihat sekaligus menetapkan aspek yang paling memiliki potensi dalam menunjang keberhasilan kerja sama daerah.

Tantangan dalam pelaksanaan kerja sama daerah ini juga dihadapkan pada perjanjian kerja sama yang tidak ditindaklanjuti. Untuk itu, peran unit kerja yang menyelenggarakan kerja sama daerah dalam mencari akar permasalahan yang menghambat tidaklanjut kerja sama daerha tersebut sampai 
menemukan solusi yang terbaik. Pelaksanaan kerja sama daerah yang dilakukan oleh pemerintah daerah pada dasarnya telah melewati tahapan-tahapan yang sudah ditentukan dalam peraturan perundangundnagan, namun demikian tidak semuanya berjalan dan dilaksanakan dengan baik. Beberapa perjanjian kerja sama daerah atau yang lazim disebut Momerandum of understanding (MoU) dengan jangka waktu tertentu belum mendapatkan perhatian sepenuhnya untuk ditindaklanjuti, sehingga apa keguanaan yang didapat dari tindakan yang dilakukan tersebut. penguasaan terhadap pemilihan sektor yang menjadi objek kerja sama daerah sampai kapasitas dan dukungan unit kerja yang terkait dalam menyelenggarakan kerja sama daerah tersebut. untuk diketahui bersama, tahapan kerja sama daerah terbagi kedalam dua tahapan besar, tahapan persiapan dan tahapan pelaksanaan. Tahapan persiapan dilakukan oleh unit kerja yang menyelenggarakan peran kerja sama daerah, di daerah masuk kepada bagian dan atau sub bagaian kerja sama yang terdapat di sekretariat daerah. selanjutnya tahap pelakasaan dilaksanakan oleh unit kerja atau SKPD yang terkatit dengan objek kerja sama daerah tersebut.

Buadya kerja sama daerah dibangun didasarkan pada kebutuhan dalam mendukung pelaksanaan kerja sama daerah. setiap pelaksana kerja sama daerah harus benar-benar mengetahui kenapa unit kerja sama daerah dibentuk yang sekanjutnya menjadi kriteria kebutuhan pembentukan organisasi tersebut,, kriteria tesebut harus dipahami oleh seluruh jajaran SDM pengelola kerja sama daerah baik dari pimpinan hingga sampai kepada staf teknis. Pada pelaksanaanya budaya tersebut dapat dibentuk dari regulasi yang ada dan aturan main dalam pengelolaan kerja sama daerah. budaya tersebut dibangun melalui lingkungan eksternal dan lingkungan internal, baik yang diadopsi dari peraturan yang lebih tinggi, pengalaman kerja sama yang terlah ada, dan pemberian bimbingan teknis yang dilakukan. Unutk lingkungan internalnya nilai-nilai yang sudah dimiiliki yang dibawa masing-masing individu dan juga norma yang tidak tertulis dalam pelaksanaan kerja sama daerah.

Pelaksanaan kerja sama di daerah dalam pengelolaan kegiatanya didukung dengan teraturan yang kuat dan menjadi pedoman dalam pelaksanaan kegiatannya. Peraturan tersebut yang nanti secara perlahan akan membentuk budya pelaksanaan kerja sama daerah pada unit yang memiliki peran tersebut. saat ini sudah ada daerah yang membentuk regulasi dalam pelaksanaan kerja sama daerah dalam bentuk peraturan daerah, diharapakan dengan adanya regulasi tersebut dapat memperlancar pada pembagi pekerjaan secara teknis. Dengan adannya peraturan daerah tersebut pemerintah daerah memiliki kekuatan dalam penyelenggaraan kerja sama daerah. Perda Kerja sama sebagai regulasi kebijakan di daerah memainkan peran penting dalam mendukung kewenanga yang dilakukan oleh pemerintah daerah dalam menjaga konsistensi pelaksanaan kerja sama daerah.
Peran dan kemampuan daerah dalam sinergikan pelaksanaan kerja sama daerah pada bidang urusan yang menjadi urusan pemerintahan baik urusan wajib dan pilihan. Pada prinsipnya penyelenggaraan kerja sama daerah yang menjadi keweanangan yang dikerjasamakan, pelaksanaan kerja sama tersebut yang disesuaikan dalam bidang urusan ditiap daerah memiliki variasi yang berbeda, yang didapat dalam penyelenggaraan pada bidang urusan pemerintahan tersebut merupakan suatu pelayanan publik serta peningkatan dan tukar pengetahuan serta keterampilan dalam penyelenggaraan urusan pemerintah daerah tersebut. masing-masing pemerintah daerah memiliki kepentingan dalam kerja sama daerah. inisasi dalam penyelenggaraan kerja sama pada bidang urusan merupakan semangat bagi pemerintah daerah untuk dapat memberikan yang terbaik dalam pemberian pelayanan kepada masyarakat. Dengan kewenangan yang dimiliki dalam menjalankan kerja sama daerah dengan di dukung oleh regulasi setidanya banyak yang dapat dilakukan yang masuk kedalam perencaan kerja sama daerah yang menjadi tugas para pengelola kerja sama daerah. Program dan kegiatan yang dijalankan tentunnya mendukung dan mendorong keberhasilan pelaksanan kerja sama daerah, kewenangan yang dimainkan oleh bagian kerja sama daerah memiliki arti penting. Keweanangan yang di dapat mulai dari tahap persiapan, inventarisasi objek kerja sama daerah, persiapan, pelaksanaan, dan tahap akhir kerja sama daerah. dari sana dapat disusun kegiatan.

Selain itu peran pemerintah daerah dalam kerja sama daerah mempunyai peran yang kuat dalam mendukung penyelesaian perselisihan diantara pihak yang terlibat dalam pelaksanan kerja sama daerah, disinilah diperlukan kemampuan dalam mengelola manajemen resiko pelaksanana suatu kegitan yang melibatkan berbagai pihak, kemampuan pemerintah daerah terletak pada penyiapan adendum perjanjian kerja sama daerah sesudah tersedianya informasi yang mendukung dalam mengakhiri penyelensaian tersebut. untuk itu dibutuhkan data dan informasi yang cukup serta pelaksanaan kelarifikasi terhadap dokumen atau data dalam pelaksanaan kerja sama daerah tersebut.

Intensitas keterlibatan pemerintah semakin bermakna, tidak hanya sekedar dalam forum diskusi tetapi memiliki peran sentral dan penting dalam pengelolaan kerja sama daerah tersebut. untuk itu pengetahuan dan wawasan yang harus dimiliki oleh SDM pelaksana dan teknis kerja sama daerah harus memiliki kemampuan yang memadai dalam menyelesaikan perselisiahan kerja sama daerah. Penyelesaian perselisihan tersebut dengan mengidentifikasi dan mengevaluasi kerja sama daerah, selanjutnya diadakan forum yang melibatkan semua para pemangku kepentingan dalam perjanjian kerja sama tersebut untuk bermusyawarah dan bermufakat dalam mencari penyelesaian perselisian kerja sama daerah tersebut, baik yang merupakan jenis pelayanan atau pun metode kerja sama lainnya yang dilakukan bersama. 


\section{Evaluasi Tata Laksana Kerja Sama Daerah}

Pelaksanaan kerja sama daerah yang banyak dilakukan oleh pemerintah daerah memiliki bidang kerja sama yang hampir semuanya menjadi bidang pembagian urusan pemerintahan. Bentuk pengaturan/perjanjian yang banyak dilakukan oleh pemerintah daerah dalam pelaksanaan kerja sama daerah terdapat tiga bentuk besar yang menjadi temuan dari studi ini, yaitu: 1) Joint Services: yaitu pengaturan kerjasama dalam memberikan pelayanan publik, seperti pusat pelayanan satu atap yang dimiliki bersama, dimana setiap pihak mengirim aparatnya untuk bekerja dalam pusat pelayanan tersebut; 2) Contract Services: yaitu pengaturan kerjasama dimana pihak yang satu mengontrak pihak yang lain untuk memberikan pelayanan tertentu, misalnya pelayanan air minum, persampahan, dsb. Jenis pengaturan ini lebih mudah dibuat dan dihentikan, atau ditransfer ke pihak yang lain; 3) Pengaturan Lainnya: pengaturan kerjasama lain dapat dilakukan selama dapat menekan biaya, misalnya membuat pusat pendidikan dan pelatihan (DIKLAT), fasilitas pergudangan, dsb. Dengan memiliki wilayah cakupan minimal 2 sampai dengan 5 daerah yang saling berbatasan. Pada pelaksanaan kerja sama daerah, kegiatan kerja sama tersebut menjadi perhatian dalam menjaga konsistensi pelaksanaanya untuk itu dilakukan evaluasi sehingga mengetahuan permasalahan dan dukungan apa yang dibutuhkan pada pelaksanaan kerja sama daerah.

Selain itu, evaluasi juga pada pengelolaan kerja sama daerah. dilihat dari kebermanfaatan kerja sama dalam memenuhi dan mendukung peningkatakan kesejahteraan masyarakat. Diharapkan pengelolaan kerja sama tersebut dilakukan secara tepat sehingga dapat menghasilkan nilai tambah bagi pemerintah daerah yang merupakan tujuan dari kerja sama tersebut. dalam meninjau pelaksaan kerja sama daerah saati ini setidaknya dapat melihat banyaknya jenis kerja sama yang dilakukan baik yang berbentuk pada penyediaan infrasturktur fisik dan non fisk sampai dengan peningkatan pelayanan kepada masyarakat dalam memenuhi dan memperbaiki taraf hidupnya. Evaluasi pengelolaan kerja sama daerah dimulai dari rankgaian identifikasi aspek yang paling memiliki tingkat sensitifitas yang tinggi dalam penyelenggaraan kerja sama daerah tersebut, sehingga dihasilkan aspek-aspek yang paling krusial untuk dapat dijadikan alat ukur.

Terkadang pemerintah daerah mempertimbangkan beberapa hal dalam pelaksanaan kerja sama daerah tersebut hingga pada akhirnya ada beberapa kerja sama yang sudah ditandatangani tidak dilaksanakan hingga waktu pelaksanaan kerja sama daerah habis. Pelaksanaan kerja sama daerah yang seperti ini merupakan pelaksanaan yang memiliki kontrol terhadap kegiatan yang sangat minim, sehingga pelaksanaan menjadi lepas dan tidak menghasilkan apa-apa walapun sumberdaya dan potensi daerah belum di pergunakan. Penyusunan instrumen evaluasi pelaksanaan kerja sama daerah menjadi titik yang krusial untuk menilai dan menjaga keberlangsungan pelaksanaan kerja sama daerah tersebut. evaluasi tersebut sangat penting dilaksanakan untuk menilai sejauhmana pelaksanaan dan apa dampak yang diberikan dari pelaksanaan kerja sama daerah yang dilakukan. Pelaksanaan evaluasi didasarkan padan tahapan pelaksaan kerja sama daerah yang dilakukan, SDM pelaksana baik di bagian kerja sama atau pelaksana pada tingkat SKPD sebagai sektor yang memilikin peran untuk melaksanakan tugas tersebut.

Pengawasan dan evaluasi pelaksanaan kerja sama daerah menjadi tugas TKAD (Tim Kerjasama Antar Daerah) untuk mengawasi pelaksanaan daerah yang berjalan tidak sesuai dengan perjanjian kerja sama daerah atau ada pihak yang melakukan wan prestasi pada pelaksanaan kerja sama daerah tersebut. setidanya perjanjian kerja sama daerah yang tidak ditindaklanjuti sudah dapat terdeteksi dari awal sebelum penandatanganan kerja sama itu berlangsung. Tim tersebut perlu menggali kemampuan dan kesiapan dalam peranan pengkoordinasian persiapan kerja sama daerah. setelah TKAD tersebut mampu mendeteksi dan menilai kemampuan yang dimiliki oleh unit kerja atau SKPD yang memiliki peranan pada sektor yang dikerjasamakan yang akan malaksanakan kerja sama tersebut. dengan menilai terlebih dahulu dapat menekan unit kerja atau SKPD yang akan melaksanakan perjanjian kerja sama daerah tersebut usaha untuk meinmalisir terjadinya perjanjian kerja sama yang tidak ditindaklanjuti. Selain itu juga palaksanaan kerja sama tersebut harus dilaporkan secara kontinyu setiap bulannya kepada TKAD, laporan tersebut menjadi alat bagi Tim untuk menentukan dan mengevaluasi pelaksanaan kerja sama daerah.

Di beberapa daerah, bagian kerjasama masih minim dilibatkan dalam inisiai awal kerjasama dan pelaksanaan kerjasama. Dengan sudah ditetapkan TKAD belum berjalan sebagaimana mestinya. Tim tersebut ditetapkan oleh Kepala daerah dengan melakukan beberapa tugas antara lain dalam mempersiapakan kerja sama daerah dan melakukan evaluasi pelaksanaan kerjasama daerah, sayangnya sangat minim sekali tim tersebut melakukan evaluasi terhadap pelaksanaan kerjasama daerah meningat kesulitan dalam merumuskan instrumen evaluasi yang harus ditetapkan sehingga perlu petunjuk lebih lanjut lagi dalam pelaksanaan evaluasi sehingga keberlangusngan kerjasama daerah dapat terjaga dengan baik dan dapat memberikan manfaat dan keutungan bagi pihak-pihak yang melakukan kerjasama tersebut.

Evaluasi dalam pelaksanaan kerja sama daerah yang dapat dilakukan yang secara mandiri ataupun oleh pemerintah Provinsi dan Pemerintah. dengan meilihat aspek, yaitu 1) Pemahaman Pemda, 2) Dukungan Fasilitasi Kerja sama, 3) Analisis Hukum Perjanjian kerja sama, 4) Regulasi/Kebijakan Kerja sama yang ditetapkan oleh pemerintah daerah, 5) Kesiapan Unit Kerja Pelaksana Kerja Sama daerah, dan 6) Jenis dan Kuantitas Kerja sama daerah. 


\section{SIMPULAN}

Studi indentifikasi profil kerja sama daerah, setelah melakukan studi lapangan dan melakukan analisi terhadap data, fakta dan informasi yang didapat makan dirumuskan kesimpulan sebagai berikut:

1. Pentingnya pemataan dan pengalian objek kerja sama daerah dengan mempertimbangankan manfaat dari pelaksanaan kerja sama daerah dan juga hasil yang didapat oleh pemerintah daerah dari penggunaan potensi dan sumberdaya daerah

2. Kemampuan SDM dalam melaksanakan kerja sama daerah menjadi modal utama dalam mendukung keberhasilan, untuk itu dibutuhkan jabatan yang memiliki kompetensi yang handal dalam pengelolaan kerja sama tersebut.

3. Membangun unit kerja dengan didukung oleh norma-norma dan struktur yang tepat sesuai dengan beban kerja dan kebutuhan pengetahuan yang dimiliki dalam mendukung pelaksanaan kerja sama daerah.

4. Selama ini pelaksanaan kerja sama daerah belum memberikan dampak masih kecil dalam kontribusi pembangunan daerah, beberapa pelakasnaan kerja sama daerah perlu dilakukan evaluasi untuk meningkatkan nilai kebermanfaatan kerja sama daerah dari sisi pengelolaan yang dailakukan.

\section{DAFTAR PUSTAKA}

Cahyani, Kartika. 2009. Model Kerja Sama Antar Daerah Dalam Rangka Mendukung Otonomi daerah di Daerah Istimewa Yogyakarta. Jurnal Riset Daerah Vol. VII No. 2.

Feiock, R.C. (2004), 'Introduction: Regionalism and Institutional Collective Action' in R.C. Feiock (ed.), Metropolitan Governance: Conflict, Competition, and Cooperation, hal. 3-16, Georgetown University Press, Washington, D.C.

Oran R. Young, 1992. Arctic Politics: Conflict And Cooperation In The Circumpolar North. National Academy Press Washington, D.C

Patterson, D.A. 2008. Intergovermental Cooperation. Albany, NY. New York State Department of State Division of Local Governmental Services.

Prtikno, dkk. 2004. Penguatan Kapasitas Kelembagaan Kerja sama Kartamantul, Final Report Sekber Kartamantul-GIZ Urban Quality Yogyakarta. 